\section{UNDERSTANDING THE IDENTITY OF THE THAI MUSLIM COMMUNITY OF KUDI KHAO IN THONBURI, BANGKOK}

\section{Penchan Phoborisut $^{1}$}

\begin{abstract}
Kudi Khao or Bang Luang Community is one of the oldest Thai-Muslim communities in Bangkok. Its history can be traced back to the time of the late Ayudhaya Dynasty. Some Thai Muslims migrated to the south of the Chao Phraya River. After the subsequent capital, Thonburi, was established, some had settled along the river near the capital where their descendants have resided until the present time. This Thai-Muslim community is located among diverse neighboring communities which today boast the motto of "One sub-district", three religions." Kudi Khao's unique blend of cultural identity illustrates an integration of cultural pluralism in the diverse ethnic environment of Thailand as seen through the physical features of the religious center, Kudi Khao, an Islamic mosque built in Thai architectural style and the people's way of life intertwining Thai influence.
\end{abstract}

In the post $9 / 11$ era, the global war on terrorism has been emphasized and often used as justification for stricter control for

\footnotetext{
${ }^{1}$ Lecturer, Department of New Media

Communication, Faculty of Communication

Arts, Assumption University, Bangkok,

Thailand

${ }^{2}$ Sub-district of Wat Kanlayanamit, Thonburi district, Bangkok
}

the sake of US national security. Robert Dickson Crane (2005: 159) labeled the attack on New York City's Twin Towers, a symbol of U.S. economic power, as a "hell-sent" gift to Islamophobes. In spite of journalists' or editors' good intentions to stay unbiased, media coverage could reinforce the prejudiced perception against Muslims, who are often portrayed in news coverage of the war on terrorism as belligerent and fanatic.

Meanwhile, in Thailand, over the course of 4 years, at least 3,000 lives have perished in atrocities in Thailand's restive south (Al Jazeera, 2008). The situation shows no sign of abating. As of the beginning of July, 2008, in the wake of renewed violence, a school principal in Baan Ma Hae School in Raman district of Yala was killed while on his way home after school. Thai News Agency reported the incident prompted 55 schools to temporarily close the following day. The brutality of insurgent acts is featured in news due to the new wave of violence.

Omar Farouk Bajunid pointed out, despite Thailand's Buddhists' tolerance of religious differences, bias towards Islam still persists as it engages in insurgent acts in Thailand's three southernmost provinces. The media's portrayal of southern Thailand's insurgency which involves violence allegedly caused by 'Muslim extremists' has created a distorted perception of Thai-Muslims elsewhere.

The Union of Catholic Asian News reported Muslims in Bangkok were threatened by discrimination following the southern unrest, quoting Sawvanee Jitmoud, an academic at Rajabhat Thonburi University who said some Muslims were turned down when applying 
for a job simply because they were Muslims while some were subject to body searches by police. She reported another incident when two female Muslim teachers in Bangkok were asked by the dean to take off their veil, hijab, in front of other colleagues. The paper quoted Sawvanee as claiming, "The dean then 'demonstrated' to his staff how it was possible to hide a bomb or weapons beneath the garments," (UCANEWS, January 24, 2006).

Bajunid also noted little awareness of Thai-Muslims in other parts of the country. The heterogeneity of the Muslim community was not adequately disseminated.

This paper aims to explore the cultural identity of the Muslim community of Kudi Khao, which might not be as little known but is not adequately appreciated.

\section{Introduction}

The community of Kudi Khao where people practise Sunni Islam stands among a diverse neighborhood with communities of different faiths such as the Theravada Buddhists community surrounding Kanlayanamit Temple, the Catholics of Portuguese descendents living near Santa Cruz Church, and Mahayana Buddhists of Chinese descendants of Kudi Chine who worship at the Avalokiteshavara shrine of Kian An Ken. Each community, located within only a few minutes' walk from each other, is culturally rich and shares historical significance and a multi-ethnic background; however, they have lived together peacefully for centuries (Bangkheow 2008).

Kudi Khao used to be surrounded by canals. There were only $10-15$ houses in the area. With the surge of land prices and increasing population growth, there are now 225 households in the Kudi Khao community with about 1,100 people over a stretch of 20 rai. Conditions today are crowded, with houses along narrow alleys and walkways. Ninety-five per cent are Thai Muslims whose ancestors have lived in this community since the old days. The remaining five per cent are Thai Buddhists who rent houses in the area. Wongtimarat Khemachat (2003) mentioned at the beginning of the Rattanakosin Period in 1782, the people here were farmers and used the canals as a primary means of transportation. Since 1932, when Thailand adopted a constitutional monarchy, the economy has shifted from plantationbased to industrialization. People left their agrarian life and entered the industrialized world, working as daily workers or being employed by business owners. From interviews with elderly people, some went to work with Muslim shop owners in the Surawong area, close to today's financial district.

\section{Muslims in Thailand}

According to Omar Farouk Bajunid (1999: 221), Muslims have settled in Thailand since ancient times'. They are not a newly established community "but an integral part of the modern Thailand." There are three major groups of Muslims in Thailand: The first group is the Malay Muslims who reside in Thailand's southernmost provinces, the biggest group of Muslims in the country. The second group comprises Thai Muslims of Malay ethnicity who speak Thai and live in the upper Southern provinces. The last group is made up of a myriad of different groups of Muslims who settled in central Thailand such as Bangkok, Ayudhaya, and other provinces throughout the country. This group is composed of Persians, Malays, Moguls, Indonesians, Indians, Bengalis, 
Afghanistanis, Chinese, and Muslims from other neighbouring countries who migrated to Thailand due to economic and political reasons (Yusuf 2008: 560).

\section{Identity}

The idea of identity and its definition can be murky. Many people define the term in each specific context. A lot of times, identity tends to refer to social category defined by membership rules and (alleged) attributes or behaviors or socially distinguished qualities one takes pride in or views as unalterable but socially consequential. Nowadays, identity is a modern formulation of dignity, pride, or honor that implicitly links these to social categories (Fearon 1999).

Schwedler (2001) said identity is not a solid set of attributes but the production of historical processes and experiences through which each individual and group perceive themselves, their relationship with the people around them and their position in the world.

Lewis (1998) stated "primary" identities can be acquired by blood such as the family, the clan or tribe, and acquired by place such as the village, neighborhood, district or quarter. Religion serves as a linkage between the first two factors: the family and place in identity formation. $\mathrm{He}$ also added many people viewed religion as the only loyalty that could surpass local and immediate attachments. This is the case in the Middle East, the culture of which is determined by religion or "membership of a religious community"

For Muslims, the religion plays a pivotal role in their lives. The term Islam is the religion while the people who practise Islam are Muslims. Islamism means a multitude of different political movements in which Islam is marked as central, while Islamists are Muslims who support political schemes where the application of Islamic law is of pivotal importance. That means Islamists are Muslims but not always the other way around (Schwedler 2001).

In Islamic Culture (1992) Sawvanee Jitmoud argues that Islam is not merely a religion, but it determines a culture that administers the life of a Muslim from birth till death. As she elaborates:

Islamic culture is not a product of human imagination. Hence it does not vary with time, geography or human values. It is the duty of every Muslim to practice, spread and perpetuate Islamic culture in any society wherever he may find himself in.

\section{The identity of the Thai-Muslim community Kudi Khao}

Key informant Chai Jonsook said the people in Kudi Khao community are descendants of Cham Muslims, elaborating that a majority of Cham Muslims settled in Thailand in the Ban Krua Community in Bangkok, and where he lived right now, during the early Rattanakosin Dynasty circa 1782. Using himself as an example, Chai described Cham Muslims as small, and usually with darker skin tone as they worked in the fields growing crops and living along the canal.

Sawvanee Jitmoud (1998) mentioned that Thai Muslims in this community migrated from the former capital of Thailand, Ayudhaya when it was occupied and razed by Burma. Hundreds of Thai Muslims who 
were rafters selling things around the former capital at Tambon Hua Lam, Hua Ror and Takian Canal rafted down the Chao Phraya River to settle along both banks of Bang Luang Canal (or Bangkok Yai Canal). They were known as Khaek Phae, or Thai Muslims who lived on rafts along the canal.

Scupin (1988) said the history of Cham Muslims could be traced back to the Hindu kingdom of Champa from 192-1471 A.D. Cham Muslims entered Thailand in the seventh century when Iranians, Indians, Pakistanis, Indonesians, and Chinese also came into contact with the Thai Kingdom. They were mercenaries from Cambodian provinces. That Cham Muslims, who were mostly Sunni, during the $19^{\text {th }}$ Century, settled in Ban Krua Community (near today's National Stadium) mentioned by key informant Chai was confirmed by Scupin's findings in 1988. They adopted an agricultural lifestyle, and fished in the canals of Ban Krua. Some were artisans building boats, like the Cham Muslims in Kudi Khao. As Scupin described, Cham Muslims, most of whom settled in Ban Krua, made up a Muslim community that was a "well-integrated, self-sufficient sociopolitical enclave".

This quality of the Cham Muslims is prevalent in Kudi Khao Community where the descendents have become well adapted to the host country.

Today, no one in this community speaks Cham. No one knew what Cham language was like. Indeed, only a few people know they are Cham Muslim descendants. The people in the community no longer identify themselves as Cham Muslims.

Scupin noted this was not uncommon among other Muslims in Bangkok, adding that the economic, social and political conditions in Bangkok were driving Muslims in Bangkok to diminish the emphasis on their ethnic background and to assimilate into the Thai-ness by adopting the Thai language so as to be able to receive education in Thai public schools.

However, one thing that has prevailed in this small community of Kudi Khao over a span of two centuries is their faith in Islam, the religion they continue to practice today.

\section{Islam: Identity that prevails}

From interviews with people in Kudi Khao community, two things that people in the community take the most pride in are their faith in Islam and the symbol of their faith, the Kudi Khao mosque or Musjid Bangluang, a unique structure, featuring Thai architectural style, serving as a center of the community where Thai-Muslims conduct their religious ceremonies.

Kudi Khao (which literally means the White Structure $)^{3}$ is officially known as Bang Luang Mosque and is located on the bank of Bangkok Yai Canal or Bang Luang Canal.

It is estimated the structure was erected during the reign of King Rama I of the Chakri Dynasty. When the Thai Muslim population along the Bangkok Yai Canal augmented and Muslim rafters decided to settle on land in 1785, the existing

\footnotetext{
${ }^{3}$ The term Kudi, according to Thailand's Royal Institute's Dictionary, means an abode of religious priests such as monks or novices. However, the people of Kudi Khao community use this term in their everyday life to refer to their mosque.
} 
mosque in the areas, Tonson Mosque, located right across the Canal could not adequately accommodate the growing Muslim population. ${ }^{4}$ Chai Jonsook, a key informant of Kudi Khao community, elaborated that the mosque was built by Toh Yee, a Muslim living on a raft.

The interior and pulpit were later commissioned by Chinese merchant Chao Sua Pook, who married a Muslim woman from this community. Their descendants later adopted the family name Pookpinyo.

Kudi Khao, at a glance, can easily be mistaken for a Thai temple. The roof, made of terra cotta tiles, is reminiscent of a Buddhist temple. The tiles in green represent the color of Islam. The gable bears the symbol of Islam at the center, and is adorned with stucco flowers from China and leaves believed to have been inspired by those from a foreign country. However, it retains Islamic characteristics in its architectural structure with thirty pillars signifying thirty principles stated in the Qur'an while twelve windows and one door altogether represent the thirteen principles of daily prayer.

The structure's interior displays a combination of simple structure, with intricate Thai artistic details. This can be seen in the pulpit decorated with three spires, a colorful mosaic and gilded stucco. At the center lies a piece of wood with the Arabic alphabet. On the north side of the mosque is a Sala, a multipurpose structure of traditional Thai wooden house architecture with a raised platform. It serves as a gathering place for community members.

\footnotetext{
${ }^{4}$ From the Journal Tee Nee Tonson, a community publication by Ton Son Mosque.
}

The mosque was not the first structure that boasts Thai architectural features. Tonson Mosque, built on the opposite side of the Bangkok Yai Canal by Cham Muslim mercenaries in the $16^{\text {th }}$ Century, at one point was also built with elaborate Thai patterns mixed with a touch of foreign influence. Although the Mihrab, a Muslim artistic arch placed in the mosque to indicate the direction of the Ka'bah made in the style of the Ayudhaya period are still kept inside the Ton Son Mosque, in 1954, the original structure was replaced with the current one with a dome structure which looks completely different. ${ }^{5}$

That makes Kudi Khao the only remaining mosque with Thai architectural style in Bangkok and one of the very few remaining mosques in Thailand that embodies a strong Thai influence.

From field interviews, people of Kudi Khao Community view their mosque as a unique community identity, heavily reinforced by visitors to their community.

Visitors to the mosque come from as far away as Malaysia. A Malaysian television crew heard about this Thai influence and produced a special documentary on the community's mosque. The incident prompted the people in the community to be more aware of this community treasure.

During the past few years, cultural tourism projects have been launched, one of which was initiated by the Bangkok Metropolitan Administration (BMA) in collaboration with Rajabhat Institute Ban Somdej Chao Phraya University to research routes and

\footnotetext{
${ }^{5}$ Masjid Tonson Kab Choomchon Bangkok (Tonson Mosque and the Bangkok Community), a brochure distributed by Tonson Mosque.
} 
tourism potential of this community and the neighboring areas.

That brought more tourists, both locals and foreigners, into the area by boat and bicycles. Children in the community have reacted positively to tourists and view their mosque Kudi Khao as a source of pride.

The unique identity of Kudi Khao is recognized by the Buddhist Kanlayanamit Community, located down the Bang Luang Canal or the Bangkok Yai Canal where it meets the Chao Phraya River. Both communities are separated by the Arun Amarin Tad Mai Road. According to Arunee Sophokanlayanaskul (Interview on July 3, 2008), one of the Kanlayanamit community leaders, people in her community acknowledge the uniqueness of Kudi Khao's architecture.

The pride in the community's identity is also fortified by recognition from outsiders, particularly those in power and politics. Another structure which was the most talked about subject when people in this community were talking to visitors was the Sala structure, which is a multipurpose gathering place built in Thai style. The thing that seems to have attracted people's attention was the huge size of the renovation budget allocated by the Bangkok Metropolitan Administration 12 million baht. During informal talks with community members, some, especially elderly people smiled coyly when talking about the budget for the Sala's renovation. Some were hoping it would serve as a museum to feature the history of the community. Meanwhile, children are happy just to play with their friends under the Sala.

\section{A shared history and identity of Thai Muslims in Thonburi}

Kudi Khao is sharing its history and identity with other Thai Muslim communities, especially its high profile Tonson Mosque. Its influential neighbors at the Tonson Mosque settled on this site by the Bangkok Yai Canal as early as the Ayudhaya period, during the reign of King Chairajathirat (1534-1546). The Thai Muslims in Tonson community cited in their publications to promote their history that they were descendants of top brass General Chao Phraya Chakkreesriongkaraksa (Mud) who played a great part in collaborating with King Thaksin the Great to liberate the Kingdom from Burmese occupation over 200 years ago. Also, Tonson Mosque's Kubur or Cemetery is where nine prominent political figures were buried including Phraya Rajabangsan (Chim), the naval commander during the reign of King Rama III, and Muslim Princess Consorts namely Chaochom Hong Sa of King Rama I, Chaojom Jeeb of King Rama II and Chaochom Lami of King Rama ${ }^{6}{ }^{6}$

Although Kudi Khao does not have a specific record of direct lineage from top military leaders, the people in this community view themselves as part of a big "Muslim family" who contributed to the formation of the Kingdom's former capital, Krung Thonburi, where the Kudi Khao community lies. They also view their ancestors as having played a vital role in fighting for Thailand's independence (Informal conversations with community members).

\footnotetext{
${ }^{6}$ Masjid Tonson Kap Chumchon Bangkok (Tonson Mosque and the Bangkok Community), a brochure distributed by Tonson Mosque.
} 
Miss Arunee Sophokanlayanaskul from Kanlayanamit community explained it was widely known in her Buddhist community that the Muslim community and their ancestors had contributed significantly to rebuilding the country and serving Thai kings in the past. She added that children in her community also knew about this since they attended the same schools as children from Kudi Khao community, although formal education, such as history lessons, might not elaborate on this historical fact.

\section{Kudi Khao community's fluidity and assimilation expressed in language}

Besides the practice of Islam and their shared history of Thai Muslim military leaders, the way of life of Kudi Khao's Thai Muslims is built around their interpretation and malleability of language and culture, instead of a single cultural hegemony.

Language is one of the most important factors for an ethnic group to assimilate to a host country. All Thai Muslims at Kudi Khao identify themselves as Thai citizens. As mentioned earlier, the people have little attachment to their ethnic background of Cham Muslims. Parents send their children to government schools. Although they study Arabic to be able to read the Qur'an, in their daily life, they speak Thai.

Thai Buddhist terms were adopted by Thai Muslims in Kudi Khao to express ideas, references or ceremonies in Islam. From my observation, when a young mother is talking about a mosque, she uses the term Kudi. Some even pronounce the word as Kadi. This term is defined in Thailand's Royal Institute's Dictionary as an abode of religious priests such as monks or novices. Thai often think of it as a place where Buddhist monks reside.

Another obvious example includes the use of the term Tham Bun, a Buddhist term for making merit. The term is used by people in the Kudi Khao community when they mean the Islamic zagat or donation or original tax imposed by Muhammad on wealthy members of the community to assist the poor. The Royal Institute's Dictionary gives the meaning of the term as merit making, giving food to monks, giving things to monks. Although the idea is to share and give things to help others, a more accurate term Tham Than, which means to donate, was not used in conversations among the community members.

When asked about festivities in the community, some children said they liked the 'New Year' celebration. However, they did not mean the international New Year's Day which falls on January 1, but the Eid al-Adha, or the Hari Raya Korban or Hari Raya Haji, which means the Celebration of Sacrifice Day or the Celebration of the Hajj. It falls on the $10^{\text {th }}$ day of the month of Dhul Hijja of the Islamic calendar. On this day, people visit their parents, relatives, families and friends. It is the time when the Muslims make donations to help those in need.

The Thai word Pacha or cemetery in a Thai context seems to subconsciously carry a context of ghosts and 'scary' imagination when the people informally recalled the early days of their lives when they had to walk past Kalaya Temple's cemetery to get to the main road. The term was not used to refer to anything Islamic but to Thai ethnic beliefs, particularly in ghosts or spirits. Buddhism does not focus 
on ghosts or spirits; however, Thais often associate the idea of ghosts with the Thai cemetery. Some older people in their fifties said they did not dare walk through the $\mathrm{PaCha}$, especially when it starts to get dark while some simply dreaded the idea, saying it was too scary. However, when the conversations centered on the idea of death and living next to a Kubur or Islamic cemetery, the people did not express the same reaction, as they believed those who passed away would be at peace with God.

\section{Kudi Khao community's fluidity and assimilation expressed in culture}

The fluidity of cultures is dominant as seen through the diverse traits of the people's daily life such as Thai food, the way people dress, certain practices to celebrate life adopted from the Thai way of life and participation in multicultural activities.

The dietary assimilation can be attributed to strong economic values. According to key informants, they informally learned how to cook food, specifically Thai food and desserts, from other elder relatives, sometimes friends' relatives and later realized the food carried economic significance as they could make a living out of selling these foods in and outside their community.

The food the community offers for sale to their community members can be considered ethnically Thai without pork. The items offered by stalls around the mosque include noodles, northeastern food such as papaya salad ${ }^{7}$, beef salad, seafood

\footnotetext{
${ }^{7}$ Northeastern Thai dish made of shredded green papaya, dried shrimp, cherry tomatoes,
}

salad, deep-fried chicken sausage, deepfried catfish salad, Nam Phrik Kapi Pla Thu (a staple Thai dish of shrimp paste dip and deep fried fish), and tapioca dessert, among others.

One thing visitors might find unusual are the oversized Khanom Bueang, streetside Thai crispy pancakes that come in a thin and round shape as big as Japanese crepes. But the ingredients are a mixture of Thai custard, sangkhaya, blended with egg yolk and foithong, a Thai dessert of Portuguese origin.

The multi-faceted nature of this community's culture is based on interactions and marriage with Buddhists of ethnic Chinese background. Some families have adopted celebrations such as the Kon Phom Fai, or Phithi Tham Khwan Duean to celebrate the health of a one-month-old baby by shaving its hair. According to Prapheni Lae Phithi Samkhan Khong Thai (In Important Customs and Ceremonies of Thailand: 1973: 69-72), the ceremony is held to mark the baby's safety and health. The Thai practice as described in the book, involves a monks' sermon, a Brahman sounding a seashell, and a traditional Thai musical ensemble to give blessings to the newborn. After the baby's hair is shaved

seasoned with fish sauce, palm sugar and lime. Laos and Cambodia also share a similar dish with some variations. It is a staple dish, carrying high economic value as it is popularly enjoyed by Thai people in all parts of Thailand.

${ }^{8}$ This traditional Thai ceremony to celebrate a one-month old newborn's health has some variations. Sometimes a group of monks are invited to give a sermon without a Brahman. The monk cuts the first lock of hair of a baby boy. In the case of a baby girl, its father will perform this task. 
(this is optional), the Brahman bathes the baby in auspicious water and puts the baby in a cradle.

However, in this Muslim community's, variation of the Khwan ceremony, the health of the baby is celebrated when it is 15 or 30 days old and no Buddhist monks are present. The celebration is joined by friends and relatives of other beliefs and religions.

The adoption and adaptation of this ceremony are not unusual. Scupin (1988) noted how the idea of khwan, a Thai Buddhist concept of the human spirit, was an example of the integration of "cultural milieu" shared by Thai Buddhists and Thai Muslims in southern Thailand.

The concept is somewhat analogous to the Malay notion of semangat. It is not synonymous with The 'human soul', it may become unstabilized and there are periodic rites to revitalize or secure its presence within the body.

(Scupin 1988: 35)

According to www.prapayneethai.com, this ceremony is performed among Thai Muslims in Thailand's southern province of Satun, with a predominantly Thai Muslim population. It depicts the ceremony with the father of the baby inviting the Imam, a midwife and neighbors to participate. When the baby is 7 days old, the mother will bathe her baby and put it on a pad. Then a small date is put on a plate, prepared on a tray along with a bowl for the baby's hair, scissors and blades. Either the Imam or the midwife will shave the baby's hair. Then everyone says a prayer for Nabi. After that, the Imam says the Dua prayer. After the ceremony, the guests are served food.

\section{Social interaction among nearby communities}

Social interaction among diverse neighboring communities fosters collaboration and strengthens communities to face challenges. Factors contributing to such interaction of multiple identities can be attributed to schools, local events and social cooperation.

\section{Schools}

The people in Kudi Khao are still striving to encourage their young children to receive education. From interviews, children in the community all go to Thai schools, mostly public ones. A lot of people recognize the fact that a Bachelor's Degree would be important to advance in their career. Some attended evening schools to earn a Bachelor's Degree.

To comply with the government's law on compulsory education, all Thai Muslim children are attending schools in the neighborhood, which are made up of Buddhist and Catholic- oriented ones, for example, Kanlayanamit School, SangArun School, and Santa Cruz Sueksa School, Santa Cruz Convent, Wat Prayurawongsawat School, and Sueksa Nari School, among others. Islamic teaching sessions are available to children on weekday evenings from $6-8 \mathrm{pm}$. Schools are also where students of different religions and communities can learn and share their opinions and face cultural integration. Due to close proximity of these schools, it is not uncommon to hear students' chanting Buddhist prayers from the Buddhist school 
in a Catholic school. Recognizing different religious practices, schools allow Thai Muslim students to stay in libraries when there are Buddhist ceremonies such as the parade to mark the beginning of Buddhist Lent, or Khao Phansa Day. However, some Thai Muslim or Thai Catholic students join their friends in the parade in which there are no monks.

The school setting forges lifelong friendships that people of these communities still foster and it is where they learn about each other's cultural heritage and history reinforcing their ties and understanding of cultural differences.

\section{Local events}

Kudi Khao community leaders also invite other community leaders such as the abbot of Kanlayanamit temple, the priest of Kudi Chine or Santa Cruz Church to join their celebrations and events by sending them letters of invitation (Ruenbanthoeng 1999: 87). One community member said the food and desserts of Kudi Khao could attract a large number of people to the community and the food sold like hot cakes during festivals. According to interviews, people in Kudi Khao mentioned the word Tham Bun, ${ }^{9}$ when referring to an annual alms giving event.

Meanwhile, Thai Muslims also participate in other communities' festivities. The community leader at Kanlayanamit said the celebration to mark the founding day of the main Buddha image Luang Phor To, was one of the biggest events for binding people of different communities together.

This is a unique identity for all of the communities around here. The

${ }^{9}$ A Buddhist term referring to merit making. diversity of the neighborhood was highlighted during the event when representatives of three communities were participating in this event selling things right next to each other under the same tent. It was presided over by HRH Princess Somsawali.

(Arunee Sophokanlayanaskul, Interview on July 3, 2008)

According to Kudi Khao community member Pongsakorn Pongpiromsri, Thai Muslims can not attend other religions' activities, for example, Thai ordinations, and the Kathin ceremony, which is a Buddhist merit-making event to mark the end of Buddhist Lent. However, they can attend the wedding of a friend, a funeral or housewarming event or National Children's Day as these are social events that express warmth and care towards other human beings. Other community members affirmed a similar perception, explaining that if an action or event is not prohibited or does not go against the teachings in the Qur'an, they may participate.

\section{Social and development cooperation}

Social cooperation among Kudi Khao and other neighboring communities includes fire fighting training, health promotion, and community development. A shared sense of identity of physical conditions similar to other neighboring communities emerged. Like Kanlayanamit or Kudi Chin, Kudi Khao's layout is made up of small wooden houses densely surrounding the religious center.

The narrow alleys leading to the community make it impossible for fire trucks to enter; therefore, properly 
implemented firefighting measures are a necessity. The leaders of these communities joined forces to set up training sessions and seek sponsorship for fire extinguishers to be installed in their communities. A volunteer fire fighter said several fires had broken out over the past ten years and the volunteers were able to put them out within 30 minutes, keeping damage to a minimum, adding that no major blaze had occurred.

Before the national 30 baht health program was introduced, people in the community had little access to health resources. This prompted communities to coordinate and share the resources. A mobile medical unit which provided free medical services was set up in their community. They also set up their own first-aid health centers with volunteers taking turns to run the facility.

The community's sense of being Thai citizens and eligible to a share of development aid provided by the government as well as an ability to negotiate support for politicians in favour of their community's development is evident. Kudi Khao community's development needs are well attended by politicians and government officials, especially the Bangkok Metropolitan Administration (BMA), which contributed to major changes. The community used to be flooded and filled with trash which surfaced after the flood water receded. The BMA constructed concrete pavements, built a dam to prevent flooding, and introduced a waste management system. The BMA also set aside a 12-million baht budget for the renovation of the community's multi-purpose Thai structure located next to the mosque.

\section{Conclusion}

The identity of people in this community is built on their religion of Islam which heavily influences their way of life, their shared history of their ancestors who had significant roles in the Thai court and served Thai kings and the fluidity of cultures and modernization which they have adopted and still practice.

Thailand is not composed of one single characteristic. As Connors (2007) maintained: "the expressions of Thai-ness are not fixed territorially, but take shape in creative interaction with non-Thai elements."

The existence and integration of multiethnic cultures in Thailand, in this case, the interaction and cultural integration between Thai Buddhists and Thai Muslims, has been a defining feature of Thai society for centuries.

Kudi Khao symbolically represents a society where we can see different cultures and faiths mingle and co-exist. It is historical evidence of a fusion of Thai and Muslim influences reflected in their everyday life. More importantly, the pluralistic integration of identities and their mosque symbolically serves as an example of cultural and religious tolerance, living proof of what Yusuf (2007) described: some are comfortable embracing Thai Muslim identity or "even see being Muslim and Thai as compatible."

\section{References}

Abdullah, Zain. 2008. Negotiating Identities: A History of Islamization in Black West Africa. Journal of Islamic Law and Culture 10.1: 5-18. 
An'Na'im, Abdullahi. 2000. Human Rights and Islamic Identity in France and Uzbekistan: Mediation of the Local and Global. Human Rights Quarterly 22: 906-941.

Al Jazeera. 2008. March 21. http://english.aljazeera.net/news/asiaPacific/2008/03/200852512465526498. .html

Bajunid, Omar Farouk. 1999. The Muslims in Thailand: A Review, Southeast Asian Studies 37.2: 210 234.

Bangkheow, Phisanu. 2008. Kudi Chine Lae Puentee Kiaoneung: Choomchon Nayu Pue Karnthongtiao Tee Youngyuen (Kudi Chine and its neighbors: Pleasant community with sustainable tourism potential) Tee Tat Wattanatam 6: 93-106. (In Thai)

Boase, R (ed.). 2006. Islam and Global Dialogue: religious pluralism and the pursuit of peace. Burlington, VT: Ashgate Publishing.

Connors, Michael Kelly. 2007. Hegemony and the politics of culture and identity in Thailand. Critical Asian Studies 37.4: 523-551.

Crane, Robert Dickson. 2005. From Clashing Civilizations to a Common Vision. In Islam and Global Dialogue: religious pluralism and the pursuit of peace, edited by Robert Boase, pp. 159-178. Burlington, VT: Ashgate Publishing.

Fearon, James. 1999. What is Identity (as We Now Use the Word)? Paper Presented at Mimeo, Stanford University, November.www.stanford. edu/ jfearon/.

Jitmoud, Sawvanee. 1992. Islamic Culture. Bangkok: Thangnum. (In Thai)

---. 1998. The Muslim Ethnic Group in Thonburi. Songklanakarin Journal of Social Sciences \& Humanities, pp 53-67. Songkla: Songklakararin University.

Kana Rachakru. 1973. Prapaenee Lae Pitee Samkan Kong Thai (Important customs and ceremonies of Thailand) Bangkok: Sermwitbannakarn. (In Thai)

Lewis, Bernard. 1998. The Multiple Identities of the Middle East. New York: Schocken Books Inc.

Parekh, Bhikhu. 2006. Rethinking Multiculturalism, Cultural Diversity and Political Theory. New York: Palgrave Macmillan.

Ruenbanthoeng, Panita. 1999. Communication Strategies leading to the formation of Muslim Development, Community of Gudeekhow, Watkalaya Sub-district, Thonburi District, Bangkok. Master's Degree Thesis, Chulalongkorn University, Bangkok. (In Thai)

Schwedler, Jillian. 2001. Islamic Identity: Myth, Menace, or Mobilizer? SAIS Review 21.2: 1-17.

Scupin, Raymond. 1988. Popular Islam in Thailand. In The Muslims of Thailand: volume 1; historical and cultural studies, edited by Andrew D.W. Forbes, pp.31-45. Bihar (India): Centre for Southeast Asian Studies 
Union of Catholic Asian News. Thailand: Some Muslims in Bangkok Report Discrimination in wake of Southern Conflict. January 24, 2006. www.ucanews.com.

Weedon, Chris. 2004. Identity and culture: narratives of difference and belonging. Berkshire: McGraw-Hill.

Wongtimarat, Khemachat. 2003. Conservation Guidelines for Bangkok Yai Canal and its Communities. Master's Degree Thesis, Chulalongkorn University, Bangkok. (In Thai)

Yusuf, Imtiyaz. 2003. Religious Diversity in a Buddhist Majority Country: The Case of Islam in Thailand. International Journal of Buddhist Thought \& Culture 3: 131143.

---. 2007. "Many Faces of Islam." The Bangkok Post, Sunday October 7, 2007.

---. 2008. The Violence in Southern Thailand Muslim World. In The Imagined Land? Solving Southern Violence and the State in Thailand, edited by Chaiwat Satha-anant, pp. 547-589. Bangkok: Matichon.

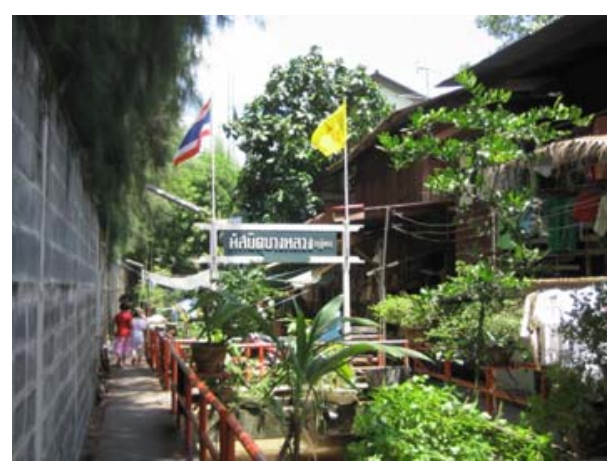

The narrow alley leading to Kudi Khao community

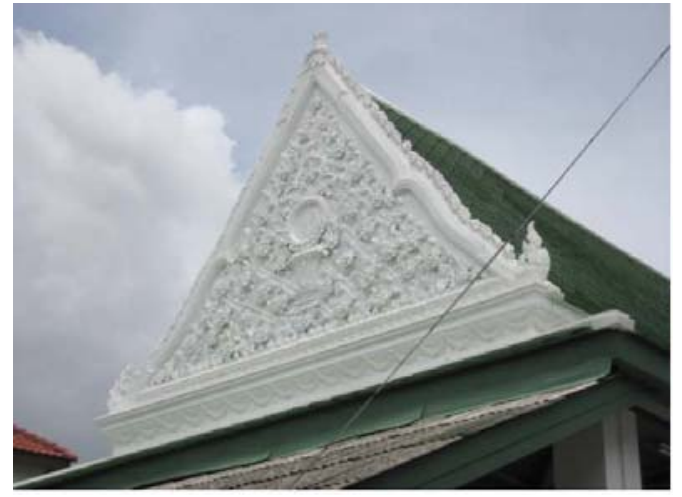

The stucco decoration on the gable

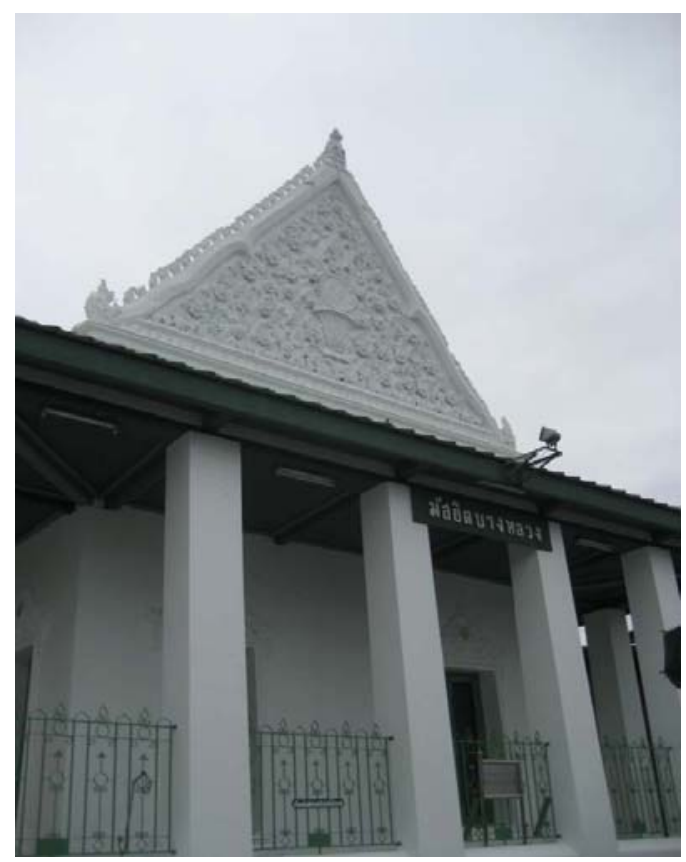

Kudi Khao or Bang Luang Mosque, featuring Thai architectural style 


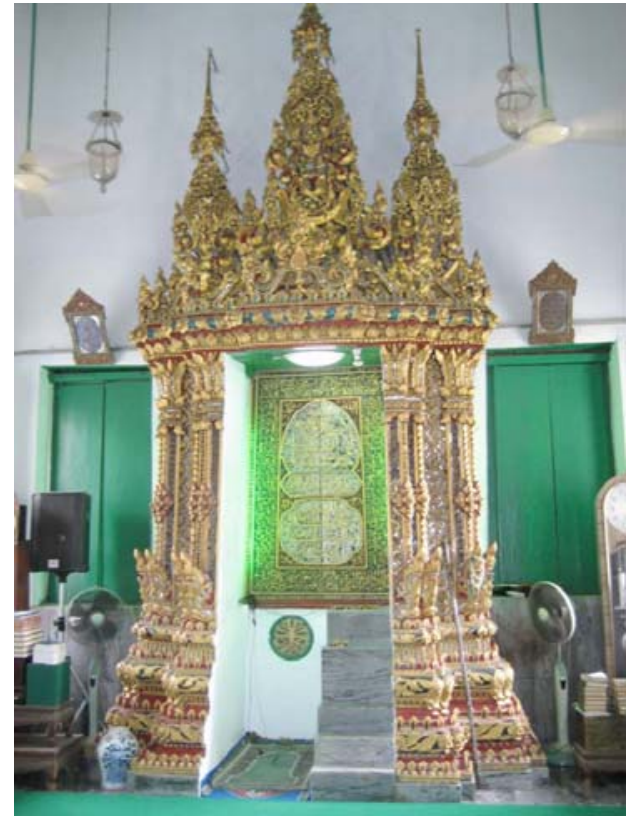

The interior of the mosque with a Thai style pulpit

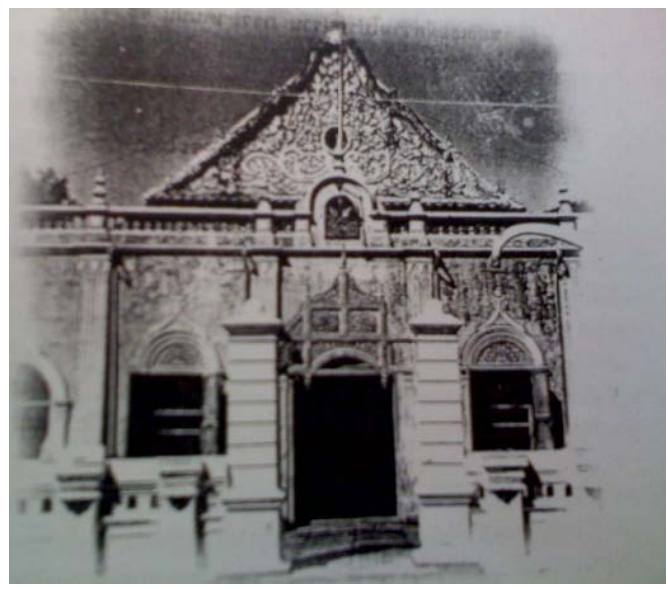

Tonson Mosque featuring Thai architectural style before it was replaced with a new one

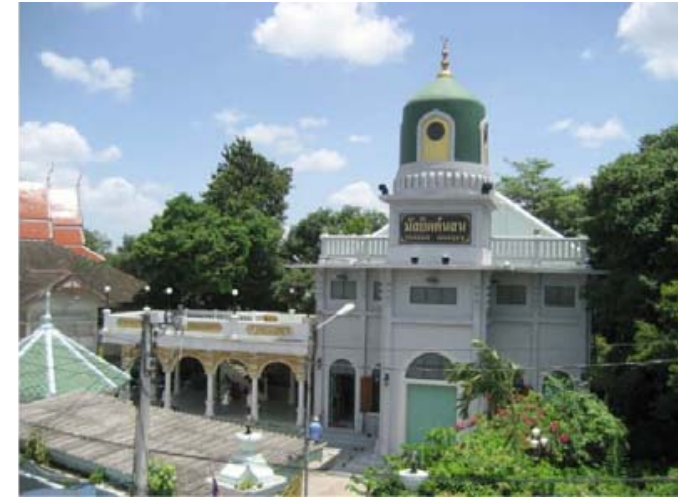

Tonson Mosque today

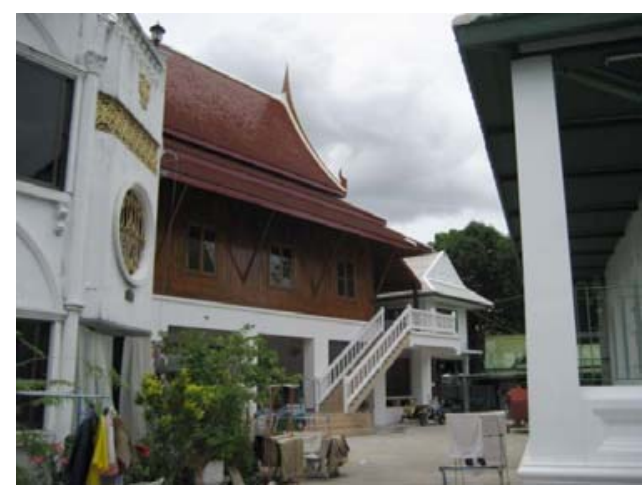

The Sala, a multi-purpose Thai structure

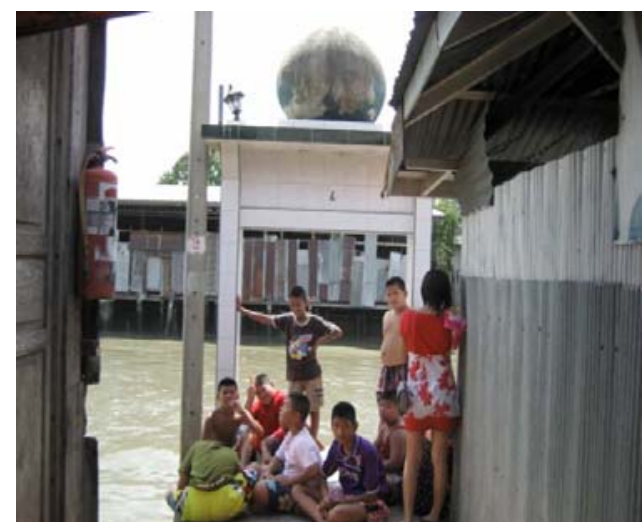

Children gather at the pier facing Bangkok Yai canal 